\title{
Classification of Pediatric Supracondylar Fractures: Comparison between the Gartland and the Lagrange \& Rigault Classifications
}

\section{Clasificaciones de las fracturas supracondíleas en edad pediátricas: comparación de las clasificaciones de Gartland y Lagrange \& Rigault}

\author{
Rita Grazina ${ }^{1}$ Márcio Oliveira ${ }^{1}$ José Marinhas ${ }^{1}$ Andreia Ferreira ${ }^{1}$ André Costa ${ }^{1}$ \\ Domingues Rodrigues ${ }^{1}$ Mafalda Santos ${ }^{1}$ \\ ${ }^{1}$ Department of Orthopaedics and Traumatology, Centro Hospitalar \\ Vila Nova de Gaia/Espinho, Vila Nova de Gaia, Portugal \\ Rev Iberam Cir Mano 2018;46:113-116. \\ Address for correspondence Rita Grazina, MD, Departamento de \\ Ortopedia e Traumatologia, Centro Hospitalar Vila Nova de Gaia/ \\ Espinho, Vila Nova de Gaia, Portugal \\ (e-mail: rita.grazina@gmail.com).
}

\begin{abstract}
Keywords

- humeral fractures

- classification
\end{abstract}

\section{Resumen}

Palabras clave

- fractura de húmero

- clasificaciones
Background The supracondylar fracture of the humerus is one of the most common fractures in pediatric age. Many classifications were proposed, with Gartland being the most widely used one and Lagrange and Rigault (L\&R) the most used in French-speaking countries. Objectives The goal of this study was to compare the Wilkins-modified Gartland classification with the L\&R classification in terms of reproducibility.

Methods Three observers with similar training levels classified 35 fractures according to both classifications twice to evaluate both intra and interobserver variation.

Results The mean intraobserver variation was 0.78 and 0.77 for Gartland and L\&R classifications, respectively, and the mean interobserver variation was 0.55 and 0.62 for Gartland and L\&R classifications, respectively.

Conclusions Both classifications reveal adequate to usage in clinical and investigational practices, which is consistent with the literature.

Introducción: La fractura supracondílea del húmero es una de las fracturas más comunes en la edad pediátrica. Varias clasificaciones han sido propuestas, siendo la de Gartland la usada de forma mas amplia y la de Lagrange and Rigault (L\&R) la más usada en países de habla francesa. Objetivo: Comparar la clasificación de Gartland modificada por Wilkins con la clasificación de L\&R en términos de reproducibilidad.

Material y Método: tres observadores, con el mismo nivel de entrenamiento, clasificaron 35 fracturas de acuerdo a las dos clasificaciones en dos ocasiones para evaluar tanto la variación intra como inter observador.

Resultados: La variabilidad media intraobservador fue de 0.78 y 0,77 para la de Gartland y L\&R respectivamente. La variabilidad media interobservador fue 0.66 y 0.62 para la de Gartland y L\&R respectivamente.

Conclusiones: Las dos clasificaciones son adecuadas para el uso en la práctica clínica e investigación, lo que es consistente con la litertura. received

July 6, 2018

accepted

October 1, 2018

published online

November 1, 2018
DOI https://doi.org/

10.1055/s-0038-1675427. ISSN 1698-8396.
Copyright $\odot 2018$ Thieme Revinter

Publicações Ltda, Rio de Janeiro, Brazil
License terms

(ㄷ) (i) $\ominus$ (5) 


\section{Introduction}

The supracondylar fracture of the humerus is one of the most common fractures in pediatric age, with extensiontype fracture being responsible for about two thirds of pediatric trauma around the elbow., ${ }^{1,2}$ These fractures were known as the "misunderstood fracture," due to common complications as Volkmann contracture and bone deformity. ${ }^{3}$

The distinction between flexion and extension types is somehow linear, with most problems rising when subdividing extension type injuries. ${ }^{2}$

The first classification for supracondylar fractures was described by Felsenreich, in 1931, and was based on fracture displacement. ${ }^{4}$ However, it was Gartland who created the first widely used classification, in 1959..$^{2,3}$

The Gartland classification divided extension-type fractures in three types: type I, nondisplaced; type II, moderately displaced; and type III, severely displaced. ${ }^{3}$

This classification was then modified by Wilkins, in 1984, to include the lack or presence of a rotational component in type II fractures. ${ }^{2,5}$

In 2006, Leitch et al added a fourth type to the Wilkins classification to include fractures with multidirectional instability. $^{6}$

Another classification was described in 1962 by Lagrange and Rigault (L\&R), which became the most used classification in France and other French-speaking countries. ${ }^{7}$ This classification divides fractures in five types. The first three are similar to Gartland, and the forth is similar to Leitch. It then incudes a fifth type of fracture classified has metaphyseal or high supracondylar. ${ }^{2}$

The purpose of all these classification systems is to guide the treatment, to help defining a prognosis for the fractures and to standardize medical communication in both clinics and investigations. To achieve these goals, a classification needs to be simple and easy to use, and a high agreement between intra and interobservers must exist. ${ }^{2,8-10}$

Nowadays, most pediatric trauma textbooks rely on the modified Gartland classification to guide the treatment. ${ }^{5}$

The aim of this work was to compare the Gartland classification modified by Wilkins with the L\&R classification in terms of intra and interobserver variation.
The fourth type of Leitch was not included in the Gartland classification as it considers clinical parameters that cannot be inferred by radiographic evaluation alone.

Classifications help the scientific community to achieve consensus when discussing clinical cases and allow treatment orientations. The establishment of a reproducible classification can help in the homogenization of studies and might simplify residents' and general doctors learning curve in terms of treatment guidelines, mainly in small centers, where there is a lack of pediatric orthopedic surgeons.

\section{Material and Methods}

A total of 35 elbow radiographs (both anteroposterior [AP] and lateral) were retrospectively obtained from the database of our center. These were obtained by searching the database for supracondylar fractures in children with both AP and lateral incidences obtained on the initial evaluation without previous reduction. The 35 most recent cases fulfilling these criteria were selected.

Three observers, with similar training levels (3 junior consultants with 7 years of training and experience in the evaluation of pediatric trauma), were asked to classify each radiograph using both classifications. Each observer had access to a diagram explaining both classifications (-Table 1). A description of the classifications can be found in - Table 1 .

The observers were then asked to classify the exact same radiographs 15 days later, so that intraobserver variation could be determined.

The statistical analysis was performed in the SPSS.23 for Mac (IBM Corp., Armonk, NY, USA) using the Cohen kappa coefficient, which was interpreted according to the standards proposed by Landis and Koch (- Table 2). ${ }^{11}$ The kappa value measures the proportion of concordant answers, considering the expected proportion related to chance. It varies between 0 and 1 , with 0 meaning complete disagreement and 1 total agreement.

Light's kappa variant was used to access interobserver variation. $^{12}$

\section{Results}

Thirty-five radiographs of 35 children were reviewed. The mean age at the time of fracture was 6.2 years, and $54.3 \%$ of the sample are males.

Table 1 Classification description ${ }^{2}$

\begin{tabular}{|c|c|}
\hline Wilkins-modified Gartland classification & Lagrange at Rigault classification \\
\hline $\begin{array}{l}\text { Type I: undisplaced or minimally displaced fracture } \\
\text { Type II: obvious fracture with displacement. The posterior } \\
\text { cortex remains intact but the anterior humeral } \\
\text { line passes anterior to the capitellum. The anterior } \\
\text { cortex is disrupted but the posterior cortex is still intact. } \\
\text { A: without rotation } \\
\text { B: with rotation } \\
\text { Type III: displaced fracture without an intact cortex; } \\
\text { with either posteromedial or } \\
\text { posterolateral displacement. }\end{array}$ & $\begin{array}{l}\text { Type I: undisplaced fractures } \\
\text { Type II: involve both cortices but with little or no displacement. } \\
\text { Type III: displaced fractures in which there is some contact } \\
\text { between the proximal and distal fragments. } \\
\text { Type IV: severely displaced fractures with no contact between } \\
\text { the proximal and distal fragments. } \\
\text { Type V: meta-diaphyseal fractures } \\
\text { (high supracondylar fractures) }\end{array}$ \\
\hline
\end{tabular}


Table 2 Interobserver variation

\begin{tabular}{|l|l|l|l|l|}
\hline \multirow{2}{*}{ Pairs of observers } & Gartland & \multicolumn{2}{l|}{ L\&R } \\
\cline { 2 - 5 } & observation 1 & observation 2 & observation 1 & observation 2 \\
\hline $01 / 02$ & 0.575 & 0.574 & 0.648 & 0.604 \\
\hline $01 / 03$ & 0.595 & 0.492 & 0.602 & 0.526 \\
\hline $02 / 03$ & 0.519 & 0.553 & 0.646 & 0.676 \\
\hline Mean & 0.563 & 0.540 & 0.632 & 0.602 \\
\hline & 0.55 & 0.62 & \\
\hline
\end{tabular}

Abbreviations: L\&R, Lagrange \& Rigault.

Table 3 Intraobserver variation

\begin{tabular}{|l|l|l|l|l|}
\hline & $\begin{array}{l}\text { Observer } \\
\mathbf{1}\end{array}$ & $\begin{array}{l}\text { Observer } \\
\mathbf{2}\end{array}$ & $\begin{array}{l}\text { Observer } \\
\mathbf{3}\end{array}$ & Mean \\
\hline Gartland & 0.877 & 0.880 & 0.596 & 0.78 \\
\hline L\&R & 0.917 & 0.881 & 0.521 & 0.77 \\
\hline
\end{tabular}

Abbreviations: L\&R, Lagrange \& Rigault.

Table 4 Interpretation of the kappa statistic according to Landis and Koch ${ }^{11}$

\begin{tabular}{|l|l|}
\hline Value of Kappa & Interpretation \\
\hline$<0.21$ & Very poor \\
\hline $0.21-0.40$ & Poor \\
\hline $0.41-0.60$ & Fair \\
\hline $0.61-0.80$ & Good \\
\hline $0.81-1.00$ & Very good \\
\hline
\end{tabular}

The mean interobserver variation was 0.55 and 0.62 for the Gartland classification and the L\&R classification, respectively (-Table 2 ).

The mean intraobserver variation was 0.78 and 0.77 for the Gartland classification and the L\&R classification, respectively ( - Table 3 ).

According to Landis and Koch ${ }^{11}$ (-Table 4), both classifications reach full intraobserver agreement, but only the L\&R classification reaches full interobserver agreement, with the Gartland classification showing only moderate agreement.

\section{Discussion}

Classifications are intended to facilitate communication between clinicians and investigators, as well as guiding the treatment. To serve these purposes, they must be reproducible.

In the present study, the interobserver variation obtained for the modified Gartland classification is similar to that found in literature. Mallo et $\mathrm{al}^{13}$ showed a kappa of 0.52 ; Heal et $\mathrm{al}^{14}$ of 0.54 , and Barton et $\mathrm{al}^{15}$ a slightly better score of 0.74 .

Regarding intraobserver variation, the results obtained are also comparable to those described in the literature. Mallo et $\mathrm{al}^{13}$ achieved a kappa of 0.723 ; Heal et $\mathrm{al}^{14}$ of 0.77 , and
Barton et $\mathrm{al}^{15}$ of 0.84 , when comparing the radiographs with a 2-week interval and of 0.81 with a 9-month interval.

The classification of L\&R is much less studied, which reflects the comparatively wider use of the Gartland classification. Nevertheless, the results obtained are similar to those of de Gheldere et al, $^{16}$ who obtained an intra and interobserver variation of 0.76 and 0.69 , respectively.

Limitations to this study may be the small sample size and the use of radiographs that sometimes failed to be adequate anteroposterior and lateral acquisitions, mainly due to pain elicited while manipulating the upper limb. On the other hand, it approaches clinical practice, as most radiographs obtained in the acute setting lack perfect acquisition.

Additionally, the use of the Wilkins-modified Gartland classification may increase classification difficulty, leading to underestimated results.

\section{Conclusions}

As it is well known, the quality of a classification is given by its intra and interobserver reliability.

Through this analysis, it is possible to conclude that both classifications show a similar intra and interobserver variation and both are adequate for usage in clinical and investigational practices. Nevertheless, the L\&R classification shows a trend to better interobserver correlation, but larger studies are needed to confirm this hypothesis.

Conflicts of Interest

Authors declare no conflict of interest.

\section{References}

1 Abzug JM, Herman MJ. Management of supracondylar humerus fractures in children: current concepts. J Am Acad Orthop Surg 2012;20(02):69-77

2 Agashe M. Classifications of Supracondylar Humerus Fractures: Are they Relevant? Are we Missing Something? International Journal of Paediatric Orthopaedics 2015;1(01):6-10

3 Gartland JJ. Management of supracondylar fractures of the humerus in children. Surg Gynecol Obstet 1959;109(02):145-154

4 Felsenreich F. Kindliche supracondylaive fracturen und posttraumatisch deformotaten des ellenbogen gelenhes [in German]. Arch Orthop Unfallchir 1931;29:555-559

5 Wilkins KE. Supracondylar fractures of the distal humerus. In: Rockwood CA Jr, Wilkins KE, Beaty JH, eds. Fractures in Children. 4th Ed. 
6 Leitch KK, Kay RM, Femino JD, Tolo VT, Storer SK, Skaggs DL. Treatment of multidirectionally unstable supracondylar humeral fractures in children. A modified Gartland type-IV fracture. J Bone Joint Surg Am 2006;88(05):980-985

7 Lagrange J, Rigault P. [Treatment of supra-condylar fractures of the humerus in children [in French]. Presse Med 1970;78(53):2382

8 Audigé L, Bhandari M, Kellam J. How reliable are reliability studies of fracture classifications? A systematic review of their methodologies. Acta Orthop Scand 2004;75(02):184-194

9 Garbuz DS, Masri BA, Esdaile J, Duncan CP. Classification systems in orthopaedics. J Am Acad Orthop Surg 2002;10(04):290-297

10 Slongo T, Audigé L, Schlickewei W, Clavert J, Hunter J; International Association for Pediatric Traumatology. Development and validation of the $\mathrm{AO}$ pediatric comprehensive classification of long bone fractures by the Pediatric Expert Group of the AO Foundation in collaboration with AO Clinical Investigation and Documentation and the International Association for Pediatric Traumatology. J Pediatr Orthop 2006;26(01):43-49
11 Landis JR, Koch GG. The measurement of observer agreement for categorical data. Biometrics 1977;33(01):159-174

12 Hallgren KA. Computing Inter-Rater Reliability for Observational Data: An Overview and Tutorial. Tutor Quant Methods Psychol 2012;8(01):23-34

13 Mallo G, Stanat SJC, Gaffney J. Use of the Gartland classification system for treatment of pediatric supracondylar humerus fractures. Orthopedics 2010;33(01):19

14 Heal J, Bould M, Livingstone J, Blewitt N, Blom AW. Reproducibility of the Gartland classification for supracondylar humeral fractures in children. J Orthop Surg (Hong Kong) 2007;15(01):12-14

15 Barton KL, Kaminsky CK, Green DW, Shean CJ, Kautz SM, Skaggs DL. Reliability of a modified Gartland classification of supracondylar humerus fractures. J Pediatr Orthop 2001;21(01):27-30

16 de Gheldere A, Legname M, Leyder M, Mezzadri G, Docquier PL, Lascombes P. Reliability of the Lagrange and Rigault classification system of supracondylar humerus extension fractures in children. Orthop Traumatol Surg Res 2010;96(06):652-655 